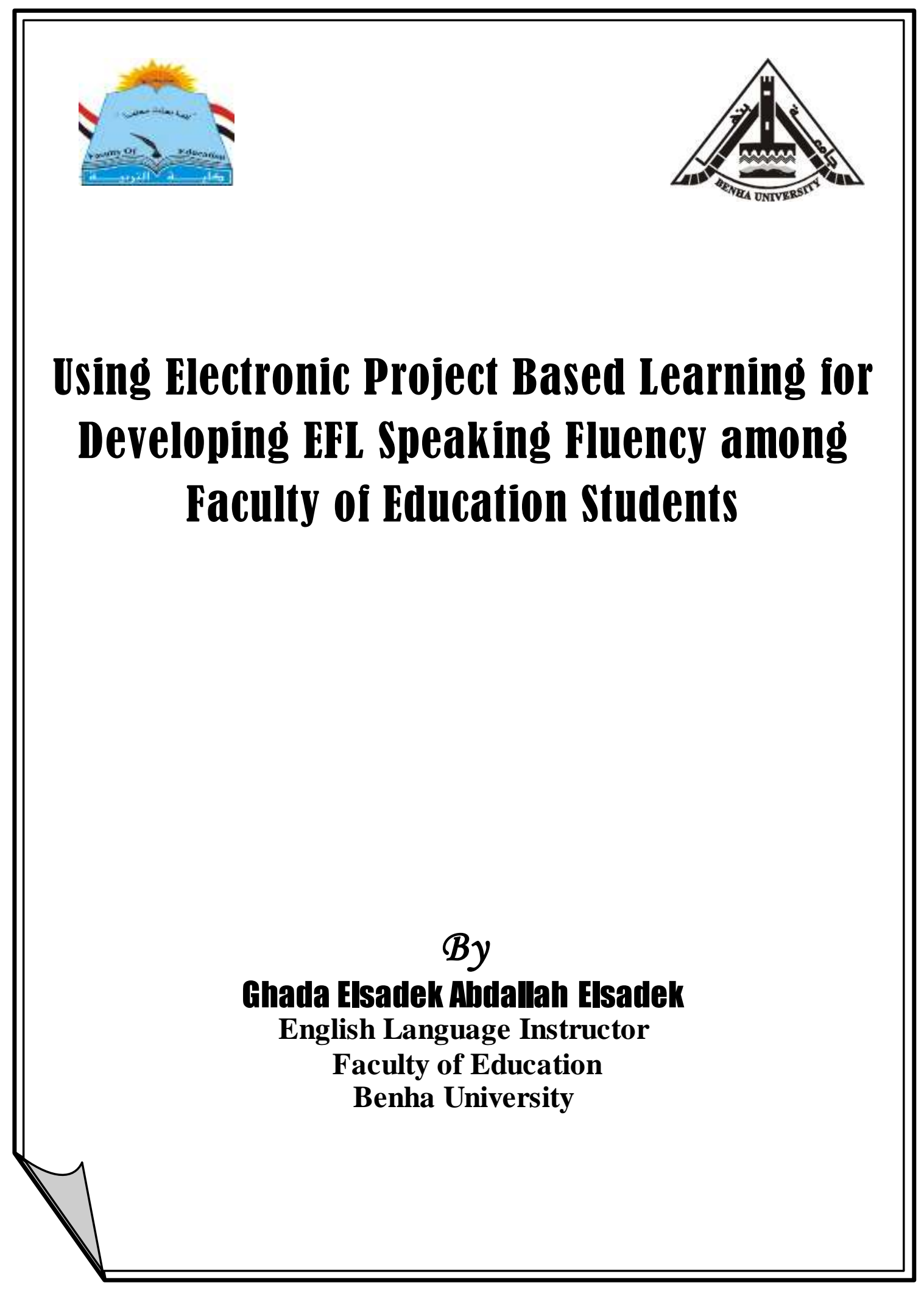




\title{
Using Electronic Project Based Learning for Developing FFL Speaking Fluency among Faculty of Education Students
}

\author{
By \\ Ghada Elsadek Ahdallah Elsadek \\ English Language Instructor- Faculty of Education- Benha University

\section{Dr. Eman Mohammed Abdel-Haq Dr. Magdy Mohammed Amin} \\ Benha University, Faculty of Education
}

\begin{abstract}
Ahstract
This study aimed at developing EFL speaking fluency skills among faculty of education students using electronic project based learning (EPBL). the participants of the study consisted of first year English section students enrolled in faculty of education, Benha university $(n=27)$. the study followed the one-group pre-post test design. four main tools were used; an EFL fluency skills checklist required for freshmen students, an EFL pre-test fluency test to measure students' fluency skills, an EFL posttest fluency test to measure students' fluency and an EFL fluency skills rubric to score and analyze students' performance on the EFL fluency skills tests. a quantitative data analysis was conducted. t-test was used to compare the means scores of the pre-test and the post-test of the study participants. the EPBL was implemented to the participants during the first semester of the academic year 2017/2018. results of the quantitative analysis showed that the participants' EFL speaking fluency skills were developed significantly as a result of implementing the EPBL. therefore, it can be concluded that that the EPBL is effective in developing the EFL fluency skills among EFL first year students.
\end{abstract}

Keywords: EFL speaking skills, EFL fluency skills, electronic project based learning (EPBL).

\section{1}


يهدف هذا البحث الى تنمية مهارات الطلاقة فى التحدث لدى طلاب الفرقة الأولى شعبة اللغـة الإنجليزيـة كلية التربيـة جامعـة بنها و ذلك باسـخدام التعلم القائم على المشـروع الالكترونى. ولقد تم استخدام التصميم التجريبى ذو المجموعة الواحدة (قياس قبلى بعدى) وبلغت عينة الدراسة سبع وعشرون طالب. وتم تصميم قائمة بالمهارات اللازمة لهؤلاء الطلاب لمعرفة مدى توافر هذة المهارات لديهم. وتم تصميم اختبار قبلى واختبار بعدى لقياس طلاقة التحدث باللغة الانجليزيـة كلغة اجنبية. تم اختبار الطلاب قبليا لتحديد مستوى ادائهم القبلى وتدريبهم خلال استخدام التعلم القائم على المشروع الالكترونى على كيفية تنمية مهاراة طلاقة التحدث كمهارة هامة متضمنة فى مهارات التحدث. وتم تطبيق الاختبار البعدى على الطلاب لقياس مدى التقدم فى مستوى ادائهم ولقد اثبتت النتائج عن وجود فرق فى اداء الطلاب قبل وبعد تطبيق الاختبارين وذلك لصالح الاختبار البعدى مما يدل على مدى فاعلية استخدام التعلم القائم على المشروع الالكترونى فى تنمية مهارات طلاقة التحدث باللغة الإنجليزية.

الكلمـــات المفتــاحيــــة: مهارة التحدث باللغه الانجليزيه، مهارة طلاقة التحدث، التعلم القائم

$$
\text { على المشروع الالكتروني. }
$$




\section{Introduction}

Widiati and cahyono (2006) stated that English language position has been strengthened nowadays due to using it as a language for international communication. the number of students who want to learn English to communicate increased greatly. the teaching of speaking skill has become more important in English as a foreign language context. moreover Riggenbach and Lazaraton (1991) assured that if students of English as a foreign language could communicate effectively in language, they could be considered successful learners. those made a lot of students want to develop English proficiency and to value the teaching of English speaking skill.

Luoma (2009) clarified that speaking could reflect one's personality, inner image, thoughts and knowledge of the world around us. speaking is an important factor for language acquisition. it needs to be mastered by everyone, as by speaking, one can convey message, express his feeling and give opinion. speaking is a speech production that becomes a part of daily activities which involve interaction. speaking skill is the most important skill in language learning which gives learners opportunity to practice, speak fluently and arrange sentences (Elnada, 2015).

Speaking is so much a piece of day by day life that people underestimate it. the normal individual produces tens of thousands words a day, although a few people may create significantly more than that thornbury (2005). luoma, (2009) showed that if the learner mastered speaking, it could help him to master the sound system of the language and the structure of speech is quite different from that of the written language.

According to harmer (2010) there are three reasons why students learn to speak in the class, the first reason is that speaking activities give students chances to practice real-life speaking in the safety of the classroom. the second reason is that when students use speaking activities, these activities provide feedback for both students and teacher. 
finally, the more students have chances to activate the various factors of language that have been stored in their brains, the more automatic their use of these elements become. as a result, students gradually become autonomous language users. this means that they will be able to use words and phrases fluently without very much conscious thought.

According to levelt (1990) there are three speaking processes: conceptualization, formulation and articulation. conceptualization means what information the speaker should choose to express the meaning. formulation means choosing the proper words with proper grammatical structures. articulation means producing the words with the articulatory organs.

According to torky (2006) speaking is an interactive process, which involved three stages producing, receiving and processing information. but florez, (1999) and brown (2000) revealed that during speaking class would pass through five stages as shown in the following figures:

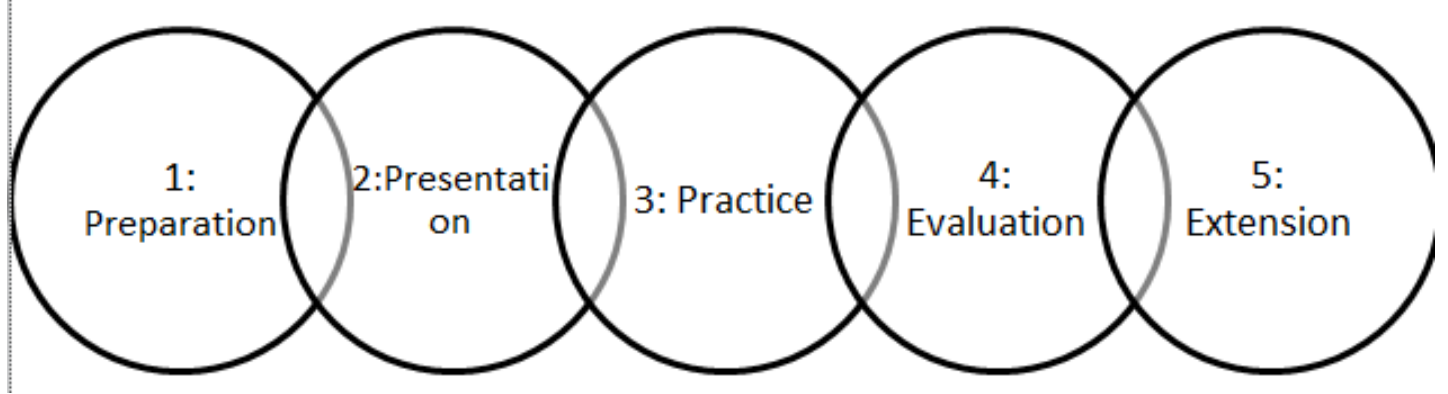

Figure (1): Stages of speaking as a process (original source)

Preparation means that the teacher would set up the context for the task using (where, when, why, and with whom it will occur) and to give attention to the speaking skill to be focused on (requesting illumination, focusing on keywords, utilizing lessened types of words). presentation consists of giving learners a preproduction model that facilitates learner understanding and helps them to turn out to be mindfully onlookers of language utilize.

Moreover practice involves learners' reproducing the focused on structure, usually in a controlled or highly supported manner. but for 
evaluation, attention will be paid to the skill being examined and requesting that learners monitor and assess their own progress. finally, extension means students' ability to utilize the strategy or the skill in a different context authentic communicative situation, or to integrate use of the new skill or strategy with previously acquired ones.

To be speakers, just learn the language. but to be good speakers, there are a lot of characteristics that good speakers should have. therefore harmer (2010), west (2013) and ashour (2014) assured that to be good speakers; speakers should prepare well before speaking, have the capacity to work with more than just words and linguistic use. they must have the capacity to string expressions together and to work with longer messages (stretches of discourse). moreover they need to recognize discourse markers and be able to use them.

Furthermore good speakers ought to stay away from long quiets, and ought to listen when another person is talking. in addition to having the capacity to expect the phonetic components and afterward to create these semantic components in their particular contextualized circumstances, they shouldn't speak the same way they write. finally it can be summed that good speakers are good writers as speaking and writing complete each other in a complete process. the following table is a comparison between good speakers and poor speakers.

\section{Table (1): Comparison between good speakers and poor speakers (original source)}

\begin{tabular}{||l|l||}
\hline \multicolumn{1}{|c|}{ Good speakers } & \multicolumn{1}{c|}{ Poor speakers } \\
\hline \hline Prepare well before speaking & Don't prepare before speaking \\
\hline Use numerous expressions & Stick to one or two expressions \\
\hline Use discourse markers correctly & Get lost while using discourse markers \\
\hline Avoid long quiets & Tend a lot to quiet \\
\hline Don't speak the same way they write & Speak the same way they write \\
\hline
\end{tabular}

Smith (2003) clarified that students won't be proficient speakers unless they expand their skills to speaking in front of their colleagues in 
the class. so using skills successfully in the class makes students ready to speak publicly. and those skills range from engaging in a simple conversation to formal public speaking. so there is a need to study speaking skills.

One important speaking skill is fluency; thornbury (2005) assured that fluency is the most important aspect; if speakers pronounce word by word, they won't be fluent speakers. fluent speakers use some production strategies like disguising pauses by filling them, also using repeating either one word or short phrases. according to brown (2000); thornbury (2005); torky (2006); huang and gui (2015) there are some features that speakers use to speak fluently like: making pauses long and not hesitating and filling their pauses; like making pauses when they are in transition point, using long runs of syllables and words between pauses, allowing the stream of the speech to flow.

Brown (2003: 2) defines fluency as "the features which give speech the qualities of being natural and normal, including nativelike use of pausing, rhythm, intonation, stress, rate of speaking, and use of interjections and interruptions."

Hormailis (2003:17) stated that the fluency is the quality or condition of being fluent. it is the capability to use the language spontaneously and confidently and without undue pauses and hesitation. rahayu (2012:62) stated that "speaking is an activity of reproducing word orally. it means that there is a process of exchanging ideas between a speaker and a listener. therefore, it is important to have fluency as having the capability of other components of speaking".

Mumford (2009) argued that all students, regardless of likely interaction with native speakers, can benefit from learning some spoken grammar features. he identified forms related to fluency, such as fillers, heads, tails, ellipsis, and phrasal chunks, which allow students to adapt to the pressure of real-time communication and speak more fluently and efficiently. 
Baker and westrup (2003: 90) illustrated speaking skill as the fluency meaning, speaking with ease and without thinking about possible errors. this gives learners a chance to experiment using the language they have learnt to communicate in a way that is similar to using English in real life

Richards (2006:14) assured that fluency is natural language use occurring when a speaker engages in meaningful interaction and maintains comprehensible and ongoing communication despite limitations in his or her communicative competence. fluency is developed by creating classroom activities in which students must negotiate meaning, use communication strategies, correct misunderstandings, and work to avoid communication breakdowns. he stated some activities that focused on fluency. these activities like; reflect natural use of language, focus on achieving communication, require meaningful use of language, require the use of communication strategies, produce language that may not be predictable and seek to link language use to context.

\section{There are sub-skills that can be listed here:}

- Making a rehearsed or unrehearsed presentation about familiar topics (self, family, immediate environment or current issues).

- Narrating a story based on personal experiences.

- Organizing the oral production both cognitively and physically.

- Showing a certain number of hesitations, pauses, backtracking and corrections.

- Using gap-fillers correctly.

- Producing language spontaneously without interlocutors.

Baş and beyhan (2010) suggested using epbl as a teaching approach. they assured that it creates a new optimal environment to practice efl speaking skills. moreover it gives the learners the opportunity to learn in an authentic environment. patton (2012) recommended using pbl as a meaningful approach. pbl provides meaningful and contextual environment to practice efl speaking skill. 
baş and beyhan (2010: 366) defined epbl as: "an instructional approach centered on the learner. instead of using a rigid lesson plan that directs a learner down a specific path of learning outcomes or objectives". castaneda (2014:159) defined pblas "an instructional model which includes a problem and finishes with an authentic product."

There are different terms that previous researchers put to define electronic project based learning (EPBL). synteta (2003) named PBL after using internet as a "project based e- learning". Kösea (2010) named PBL after using the internet "a web based system for projectbased learning". PBL guide (2011) called it "technological project based learning". in the previous term; the technology had been integrated with the project based learning. and recently zamorshchikova, egorova and popova (2011) named it "internet technology-based projects in learning". so it can be inferred that EPBL is a result on integrating both technology and internet in using project based learning.

The EPBL is an instructional approach that helps students to Learn by presenting authentic materials presented through a technological method.

Railsback (2002); Kösea (2010); PBL Guide (2011) showed that there are a Lot of Advantages and Benefits for using EPBL in Classes. EPBL helps Students to Investigate on Worthy Topics with more Details. They help to Gain Knowledge through Experience. Both of them Connect Students' Classrooms with Real World and Investigate their Own Interest. Students have the Chance to Learn by Doing. Students' Motivation is Increased. Students Communicate and Collaborate with Each other Effectively. An Expanded View of the Subject Matter is Presented. Students' Interest is Increased by Involving them in Solving Real Problems.

one of the most important benefits of using epbl according to (stoller, 2006) is improving language skills. that is because teachers use authentic activities to engage students in purposeful communication. students have the chance to use language related to natural context. teachers use authentic activities in order to develop students' thinking and problem solving skills. pbl helps students to integrate language skills. 
Depending EPBL on authentic context and students' interest increases students' motivation and enjoyment in the class (kriwas, 1999). using EPBL in class develops 21st century skills. these skills are problemsolving and higher order critical thinking. both of those skills are very important to face the new century requirements. using authentic context in the classroom helps students to develop those skills (Allen, 2004).

EPBL helps students to increase social and communication skills. after applying them in classrooms, students can easily make decisions. students' critical thinking is increased. workplace skills are improved. teachers develop their own technology skills. social and communication skills are improved. technology projects provide ample opportunities for parents, students, teachers and other community members to interact with students and their work in meaningful ways. EPBL is more suitable for different learning styles, levels, learners and learning situations.

There are four main steps in order to use a successful EPBL with students:

\section{Speculation}

This step has to start with the teacher himself. he has to map out the projects that the students will follow during the learning process (railsback, 2002). carefulness has to be put in consideration during this step. if the project is planned well, students will success in doing it. the teacher will give his students the chance to choose the topic of the project because they have the ability to decide the way they will learn with (bell, 2010).

During this stage, the students will create accounts on the website. then they will modify their information. finally they will download the attached materials.

\section{Designing the Project Activities}

Students start to look for related topics. Then they relate information and relate answers for the problem they have chosen before 
(chang et al., 2011; castaneda, 2014). Then students have to decide what steps to follow, what sources to use. And that will be through working in groups. Here the teacher will be responsible for assigning every student's Role in the group (blumenfeld et al, 1991 and papanikolaou and boubouka, 2010)

Students will log into the website again to see the new Information and messages added by the teacher.

\section{Conducting the project activities}

According to maulany (2013) this stage is time of doing. students start to gather information. and they will discuss it within the group members. they try to solve the problems that they are encountering with the help of teacher. students conduct the project and present it in front of other groups. students will use different sources to look for information. these sources are like: internet, library, magazines and elders' experiences. here students will be asked to upload their different projects on the website. also they have to download the projects of the other groups.

\section{Evaluation}

Assessment would be in different shapes: self-evaluation; from the members of the group, peer-evaluation; from the other groups and teacher evaluation (Fragoulis, 2009, Papanikolaou \& Boubouka, 2010; Maulany, 2013).

\section{This stage will be on the online and offline.}

Maulany (2013) concluded that epbl gave the students an optimal opportunity to improve students' fluency skills. permatasari (2013) assured that efl speaking fluency skills had been developed after implementing epbl in the class. but she showed that the students' performance wasn't developed in the first cycle of implementing epbl, it was developed after the second cycle of the EPBL.

\section{Context of the problem:}

Many previous researches (Mahmoud, 1991; Hassan, 2009; Ali, 2010; Diyyab, 2013; Helwa, 2013) showed some problems that face EFL 
learners while speaking like: choosing the inappropriate words, idioms, phrasal verbs and expressions, using incorrect grammatical structures, besides pronouncing vowels incorrectly, expressing the ideas in incomplete and unclear sentences.

Diyyab (2013) showed that fluency should be in many communicative language courses an initial goal in language Teaching. But in spite of the importance of the EFL speaking fluency skills, there is a lack in the EFL speaking fluency skills among first Year students Enrolled in the English section in Benha faculty of education.

To document the problem of the study, a pilot study (Appendix 1) was conducted to find out the lack of EFL speaking fluency skills among First year students enrolled in the English Section. The Participants were 27 Students of the First Year Enrolled in the English Section, Faculty of Education, Benha University during the 2017-2018 Academic Year. EFL Speaking Fluency Test was used to Assess Students' EFL Speaking Fluency Skills. The Results of the Test Revealed that there was a Lack in Student's Speaking Fluency Skills.

\section{Statement of the problem}

In spite of the importance of EFL speaking fluency skills, there's still a lack in first year students' speaking fluency skills at Benha faculty of education. so, this study is an attempt to use electronic project based learning to develop their speaking fluency skills.

\section{Questions of the Study}

To face this problem, the present study attempted to answer the following questions;

1- What are the EFL speaking fluency skills required for EFL English section first year students?

2- What are the features of the Electronic Project-Based Learning (EPBL)? 
3- To what extent does the EPBL develop EFL speaking fluency skills among EFL English section first year students?

\section{Delimitations of the Study}

\section{This study will be limited to the following:}

1- First year students enrolled in the English section at Faculty of Education Benha University.

2- Some EFL speaking fluency skills required for First year student.

\section{Participants:}

The participants of the present study consisted of EFL freshmen students (first year English Section) at the Faculty of Education, Benha University during the academic year 2017/2018. The final number of the students was (27) students who attended almost all the sessions of the treatment and the pre- and post-applications of the instruments of the study.

\section{Procedures of the Study:}

The following procedures were followed to carry out the present study:

1- Identifying the EFL speaking fluency skills required for first year English section students through:

a) Reviewing literature, speaking fluency courses specifications, national standards for teachers' preparation programs and previous studies related to EFL speaking fluency skills.

b) Preparing a checklist of EFL speaking fluency skills required for first year English section students.

c) Submitting this list to a jury to verify its validity.

d) Modifying and setting the list in its final form according to the jury's suggestions.

2- Identifying the features of the Electronic Project-Based Learning (EPBL) through:

a) Reviewing literature and previous studies related to both EPBL and EFL speaking fluency skills. 
b) Identifying the objectives, content, activities, roles of the researcher and students and evaluation techniques that would be used on the treatment.

c) Designing the instruments of the study.

d) Submitting the instruments to a jury to verify its validity.

e) Modifying and setting the instruments in its final form according to the jury's suggestions

3- Identifying the effectiveness of the EPBL in developing students' EFL speaking fluency skills:

a) Assigning participants of first year English section students into one experimental group.

b) Administering the EFL pre speaking fluency skills test.

c) Implementing the EPBL to the participants of study.

d) Administering the EFL post speaking fluency test a.

e) Comparing the results statistically.

f) Analyzing the results of the study quantitatively.

g) Interpreting the results of the study.

h) Providing recommendations and suggestions for further research.

\section{Instruments of the study:}

1- An EFL Speaking fluency Skills Checklist.

2- An EFL Pre speaking fluency test to measure students' speaking fluency skills.

3- An EFL Post speaking fluency test to measure students' speaking fluency skills.

4- An EFL speaking fluency skills rubric to score students' performance on the EFL speaking skills tests.

\section{Validity of EFL Speaking Fluency Tests:}

EFL speaking fluency tests were submitted to some of the jury members in curricula and methods of Teaching English .They were asked to indicate the suitability of the test content for the academic level 
of the study sample (First Year English Language Department Students and the clarity of the instructions for each part of the test. They indicated the suitability of the tests and how far each question of the tests assesses the skills intended to measure .Most of the jury members also indicated the suitability of the tests to its main objectives and the consistency of questions to the tests' objectives. According to the jury's' opinions and suggestions, the modifications would be performed to the tests' content to get its final form.

\section{Reliability of the pre-test}

The reliability of the test was measured using the test-retest method

\section{a) Test-retest method}

The test was administered to a group of 1st year English section students at the Faculty of Education, Benha University (other than the experimental group who received the treatment by the EPBL) $(\mathrm{N}=22)$ during the first semester of the academic year 2017/2018. Then, it was administered to the same group again after two weeks. The Pearson correlation between the two administrations was (.997) which is significant at the 0.01 level. This means that the EFL Speaking pre-test is reliable.

\section{b) Inter-rater method}

Inter-rater reliability means two or more raters/observers give consistent estimate of the same test and this method is used to avoid the subjectivity factors in grading. Accordingly, the researcher gave an English language instructor ${ }^{(*)}$ a copy of students' answers to the EFL speaking fluency pre-test and the rubric to estimate the students' answers.

Comparing the results of the two raters, it was found that the Pearson correlation was (.980) which is significant at the 0.01 level.

\section{Reliability of the post-test}

The reliability of the test was measured using the inter-rater method

(*) Ansaam Mohamed Abdelaziz Alshamy, ESP English Instructor at Benha University 


\section{Inter-rater method:}

Inter-rater reliability means two or more raters/observer give consistent estimate of the same test and this method is used to avoid the subjectivity factors in grading. Accordingly, the researcher gave an English language instructor a copy of students' answers (video) to the EFL speaking fluency post-test and the rubric to estimate the students' answers. Comparing the results of the two raters, it was found that the Pearson correlation was (.988) which is significant at the 0.01 level.

\section{Aim of the Study:}

The study aimed at developing some of the EFL speaking fluency skills for first year students, enrolled in the English section at Benha Faculty of Education. The researcher used EPBL to accomplish the study aims. By the end of the treatment students will be able to identify the importance of EFL speaking fluency skills to English language learners.

\section{The Experimental Treatment:}

The present study focused on developing the study participants' speaking fluency skills, through the use of some technological materials, traditional and online activities. The project was "Brainstorming about specific topic". The project lasted for three sessions in two weeks. The students were guided by the researcher during four stages of the EPBL. The participants started to use online website to download audios and videos about the topic of their own choice to develop their speaking fluency skills. In groups, they gathered information about the topic. They were asked to present brainstorming in front of the whole group. Then they uploaded it on the website. In addition, the study participants were asked to share their videos with their group members. Consequently, the study participants' fluency skills were developed greatly in the post-assessment of the EFL speaking fluency test than the pre assessment of the post-test due to the effect of EPBL. 
These results are consistent with previous studies which proved the great contribution of the EPBL in developing fluency skills. Maulany (2013) who assured that fluency was developed by using EPBL more than the other speaking skills. Permatasari (2013) examined the effect of EPBL on English language skills. His study involved 27 students. The result was that Electronic Project Based Learning could improve the students' speaking skill in term of students' project. He assured that fluency skills had been developed greatly among the other skills.

Table (2): the participants' mean scores, standard deviations, $t$-value and level of significance in the EFL speaking fluency skills:

\begin{tabular}{|c|c|c|c|c|c|c|c|}
\hline Skill & $\mathbf{N}$ & Application & Mean & S.D & t-Value & D.F & Sig. \\
\hline \hline \multirow{2}{*}{ Fluency } & \multirow{2}{*}{27} & Pre & 7.0741 & 2.20010 & \multirow{2}{*}{41.017} & \multirow{2}{*}{26} & \multirow{2}{*}{0.01} \\
\cline { 3 - 5 } & & Post & 22.3704 & 1.57256 & & & \\
\hline
\end{tabular}

It has been indicated that the mean scores of the study participants in the post application of the EFL speaking fluency tests are higher than their scores in the EFL speaking fluency skills; t-value is (41.017), which is significant at the (0.01) level.

Results of the present study confirmed that "there was a statistically significant difference between the mean scores of the study sample in the EFL speaking fluency test in the pre-post assessment, in favor of the post assessment .Thus, the participants showed more improvements in their EFL speaking fluency skills. This is due to the use of the EPBL, where the " $t$ " value was significant at the level of (0.01).

\section{Evaluationtechniques}

Two evaluation techniques were used by the researcher; formative assessment and summative assessment.

\section{1- Formative assessment}

Formative assessment was used for assessing the participants' progress in EFL speaking fluency skills and for providing necessary and immediate positive feedback. The activities quizzes provided the researcher with the sufficient information about the participants' progress and development in EFL speaking fluency skills.

\section{2- Summative assessment}

Summative assessment was conducted at the end of the treatment through the application of the EFL speaking fluency post-test to measure the achievement of the topics of the EPBL. 


\section{References:}

Ali, H.S. (2010). The Effectiveness of a Self-Efficacy Based Program for Developing EFL Oral Communication Skills Among Prospective Teachers. Unpublished Master thesis, Faculty of Education, Benha University.

Allen, L. Q. (2004). Implementing a Cultural Portfolio Project within a Constructivist Paradigm. Foreign Language Annals, 37 (2), 232-239. Ashour, J. M. (2014). The Effect of Using a Videoconferencing-Based Strategy on UNRWA 9th Graders' English Speaking Skills and their Attitudes towards Speaking. Unpublished Master Thesis, The Islamic University of Gaza.

Baker, J. Westrup, H.(2003). Essential Speaking Skills: Continuum. London. Baş, G., Beyhan, Ö. (2010). Effects of Multiple Intelligences Supported Project-Based Learning on Students' Achievement Levels and Attitudes Towards English Lesson. International Electronic Journal of Elementary Education. 2(3). 365-386

Bell, S. (2010). Project-Based Learning for the21st Century: Skills for the Future. The Clearing House, 83: 39-43

Blumenfeld, P. C. Soloway, E. Marx, R, W. Krajcik, J. S. Guzdial, M. and Palincsar, A. (1991). Motivating Project Based Learning Sustaining the Doing, Supporting the Learning. Educational Psychologist, 26 (3\&4), 369-398.

Brown, H.D (2000) Teaching by Principles. New York: Addison Wesley Longman.

Brown, J. D. (2003). Promoting fluency in EFL classrooms. Paper presented at the JALT National Conference. Nagoya, Japan. University of Hawai'i at Manoa, Proceedings of the 2nd Annual JALT Pan-SIG Conference.

Castaneda, R, J, B. (2014). English teaching through project based learning method, in rural area. Cuadernos de Lingüística Hispánica. pp.151-170 
Chang, C, S. Wong, W, T. \& Chang, C, Y. (2011). Integration of Project-Based Learning Strategy with Mobile Learning: Case Study of Mangrove Wetland Ecology Exploration Project. Tamkang Journal of Science and Engineering, 14 (3), 265:273.

Diyyab, E. A. E. (2013). The Effectiveness of a Blended Learning-Based Program in Developing EFL Speaking Skills and Reducing Anxiety among Faculty-of-Education Students. Unpublished Master Faculty of Education, Benha University.

Elnada, Z. (2015). The Effectiveness of Using Hot Seating Strategy on Enhancing Student-Teacher's Speaking Skills at Al-Azhar University-Gaza. Unpublished Master, Faculty of Education. Al Azhar University. Gaza.

Florez, M. A. (1999). "Improving Adult English Language Learners' Speaking Skills". The Center for Applied Linguistics

Fragoulis, I. (2009). Project-Based Learning in Teaching of English as A Foreign Language in Greek Primary Schools: From Theory to practice. English Language Teaching. Vol. 2 September 2009.

Harmer, J. (2010) How to Teach English. Harlow, England: Longman. Hassan, E.M. (2009). The Effectiveness of Two Metacognitive Strategies in Developing EFL Prospective Teacher's Speaking Skill. Unpublished Master Thesis, Faculty of Education, Benha University, Egypt.

Helwa, H.S.A.A (2013). The Effectiveness of a Self- Autonomy Based Program in Developing EFL Student Teachers' Communicative Competence. Unpublished Doctoral dissertation, Faculty of Education, Benha University.

Hormailis. 2003. The Use of Group Work Technique for theimprovement of Speaking Ability of the Second Year Studenton MAN 2 Pekanbaru. Pekanbaru: A Thesis Unpublished Paper.

Huang, Y \& Gui, M. (2015) Articulating Teachers' Expectations afore: Impact of Rubrics on Chinese EFL Learners' Self-Assessment and Speaking Ability. Journal of Education and Training Studies. 3(3). 
Kösea, U. (2010). A Web Based System for Project-Based Learning Activities in "Web Design and Programming" Course. Procedia Social and Behavioral Sciences 2, 1174-1184

Kriwas, S. (1999). Environmental education, a handbook for educators. Athens: Ministry of Education, Greek.

Levelt, W. J. M. (1990). Speaking: From intention to articulation. Cambridge, Computational Linguistics. 16(1).

Luoma, S. (2009). Assessing Speaking. United Kingdom. Cambridge University Mahmoud, A. H. (1991). A Suggested Programme for Developing the Speaking Skills Among Prospective Teachers of English in Faculties of Education Assiut University.

Maulany, D. B. (2013). The Use of Project-Based Learning Improving the Students' Speaking Skills. Journal of English and Education 1(1), 30-42.

Mumford, S. 2009. An Analysis of Spoken Grammar: The Case for Production. ELT Journal 63 (2): 137-144.

Papanikolaou, K. and Boubouka, M. (2010). Promoting Collaboration in a Project- Based E-Learning Context. Journal of Research on Technology in Education, Vol (43) N (2). (135:155).

Patton, A. (2012). Work That Matters: The Teacher's Guide to ProjectBased Learning. London, England: The Paul Hamlyn Foundation.

PBL Guide "Project-Based Learning A Resource for Instructors and Program Coordinators".(2011). National Academy Foundation and Pearson Foundation.

Permatasari, S, F. (2013). Improving Students' Speaking Skill Through

Project Based Learning for Second Grades of SMPN 1 Kawedanan, Magetan, SKRIPSI Jurusan Sastra Inggris - Fakultas Sastra UM.

Rahayu, P. (2012). Improving Students' Motivation and Speaking Skill Through Negotiated Materials Based on Current Syllabus at Grade XI Accounting of SMK.N 1 Pasir Pengaraian Rokan Hulu Riau. EDU RESEARCH; Jurnal Pendidikan. 1(1). 55:67 
Railsback, J. (2002). Project-Based Instruction. Northwest Regional Educational Laboratory.

Richards, J. C. (2006). Communicative Language Teaching Today. Cambridge University Press.

Riggenbach, H., \&Lazaraton, A. (1991). Promoting Oral Communication Skills. In M. Celce-Murcia (Ed.), Teaching English as a Second or Foreign Language (pp. 125-136). Boston: Heinie \&Heinie.

Smith, C, B. (2003). Skills Students use when Speaking and Listening. Bloomington.

Stoller, F. L. (2006). Establishing a Theoretical Foundation for ProjectBased Learning in Second and Foreign Language Contexts. Information Age Publishing.

Synteta, P. (2003). Project-Based E-Learning IN Higher Education: The Model and The Method, The Practice and the Portal. New Media in Education 263-269.

Thornbury, S. (2005). How to teach speaking. Harlow, England: Longman. Torky, S,A,E (2006). The Effectiveness of a Task- Based Instruction program in Developing the English Language Speaking Skills of Secondary Stage Students. Unpublished Doctoral Dissertation, Women's college. Ain Shams University.

West, J (2013). I Still Can't Speak English. Bookboon.com.

Widiati, U. and Cahyono, B. Y. (2006). The teaching of EFL speaking. BaHasa Dan Seni, Tahun 34, Nomor 2.

Zamorshchikova, L., Egorova, O. \& Popova, M. (2011) Internet Technology- Based Projects in Learning and Teaching English as a Foreign Language at Yakutsk State University, International Review of Research in Open and Distance Learning Vol. 12.4, 72-76. 


\section{[Appendix1]}

\section{Results of the pilot study:}

\begin{tabular}{|c|c|}
\hline Students number & Mark \\
\hline 1 & 14 \\
\hline 2 & 13 \\
\hline 3 & 15 \\
\hline 4 & 16 \\
\hline 5 & 12 \\
\hline 6 & 14 \\
\hline 7 & 15 \\
\hline 8 & 14 \\
\hline 9 & 14 \\
\hline 10 & 13 \\
\hline 11 & 12 \\
\hline 12 & 13 \\
\hline 13 & 15 \\
\hline 14 & 15 \\
\hline 15 & 14 \\
\hline 16 & 13 \\
\hline 17 & 13 \\
\hline 18 & 13 \\
\hline 19 & 14 \\
\hline 20 & 15 \\
\hline 21 & 11 \\
\hline 22 & 12 \\
\hline 23 & 12 \\
\hline 24 & 13 \\
\hline 25 & 14 \\
\hline 26 & 14 \\
\hline 27 & 14 \\
\hline
\end{tabular}




\section{[Appendix 2]}

\section{The EFL Speaking Fluency Tests:}

\section{1) Pre-test}

What do you say in these situations?

(25 marks)

1- You're having an argument with someone, but you are losing.

2- Your partner has been annoying you all day.

3- Your friends are all going out. You really want to go, but you can't make it.

4- Your co-worker keeps stealing your drink from the fridge.

5- Your friend owes you money, but you see them shopping and spending money.

\section{2) Post- test}

What do you say in these situations?

1- Your brother has been annoying you all day.

2- Your friends are all going out. You want to go with them.

3- You want to ask your co-worker for a help.

4- You want to borrow money from your friend.

5- Your sister asks a help in doing her homework. 